\title{
KARAKTERISTIK PEMBAKARAN BIOBRIKET KULIT DAN CANGKANG KARET (HEVEA BRASILIENSIS) DENGAN PEREKAT GLYSERIN
}

\author{
I Wayan Wawan Mariki ${ }^{1}$ Slamet Wahyudi², Denny Widhiyanuriyawan ${ }^{3}$ \\ 1 Jurusan Teknik Mesin Politeknik Hasnur, Banjarmasin \\ 2,3Jurusan Teknik Mesin Fakultas Teknik Universitas Brawijaya \\ JI. M.T. Haryono No. 167 Malang \\ E-mail: wawanriki44@gmail.com
}

\begin{abstract}
Some studies have been done on utilizing biomass from agriculture such as the leather and shell of rubber (Hevea brasiliensis) were not used optimally in Indonesia as an alternative energy which developed by making biobriquet to achieved the higher energy that could be used in the combustion process.. In this study, the biobriquet was made of the leather and the shell of rubber by comparisson of the leather and shell were: 0\%: $91 \%$; $45.5 \%: 45.5 \%$; $55 \%$ : $36 \%$; $64 \%: 27 \%$; 91\%: $0 \%$. Glyserin 9\% for each percentage of biobriquet was used as adhesive material and the drying temperature of $110^{\circ} \mathrm{C}$. This study aims to investigate the characteristics of biobriquet combustion which made of the leather and shell of rubber. The results shows that the biobriquet combustion process which made of $64 \%$ rubber leather and $27 \%$ rubber shell has a calorific value of 5313,923 Kal/gr. In 20 seconds of initial ignition, the combustion process shows the improvement such as increased concentrations of the flammable leather, bluish red fire.
\end{abstract}

Keywords: biobriquet, leather and rubber shell, glyserin.

\section{PENDAHULUAN}

Energi memegang peranan utama di Indonesia yang terus mengalami peningkatan dalam penggunaan energi dari 764 juta setara barel minyak. Setiap tahunnya konsumsi energi terus meningkat rata-rata $3.46 \%$. Penggunaan energi terbesar ada pada sektor industri $(37,17$ $\%)$, diikuti oleh sektor rumah tangga $(29,43 \%)$, transportasi $(28,10 \%)$, komersial $(3,24 \%)$, dan lainnya $(2,04)$, energi ini berasal dari energi fosil dan energi terbarukan disebabkan tingginya pertumbuhan penduduk Indonesia mencapai 205 juta jiwa dengan peningkatan 1,66 \% per tahun [1].

Hal ini menyebabkan pemerintah mengurangi pemakaian energi bahan bakar fosil serta mencegah terjadinya kelangkaan energi, dengan memanfaatkan energi terbarukan untuk menggurangi pemakaian bahan bakar fosil. Dengan penyediaan energi terbarukan hanya mengalami peningkatan pertumbuhan $7 \%$ per tahun dan belum sanggup mengimbangi pertumbuhan kebutuhan energi di Indonesia. Energi terbarukan yang dimiliki Indonesia yaitu biomassa merupakan proses alami yang diisi ulang terus - menerus yang dapat dikonversikan ke bahan bakar padat, cair, maupun gas sebagi sumber energi alternatif dengan potensi biomassa sebesar 103 juta ton per tahun yang baru dimanfaatkan sebagai energi alternatif sebesar $42 \%$ [2].

Biomassa memiliki sifat fisik seperti jenis dan ukuran yang tidak seragam yang berasal dari berbagai sumber seperti limbah industri, pertanian, peternakan dan limbah kota dengan kadar air tinggi serta kandungan energi yang rendah akan mengakibatkan biaya lebih tinggi dengan pemanfaatan biomassa, dengan kondisi tersebut dapat dilakukan pengolahan biomassa yang mudah dan murah sebagai bahan baku dengan mengubah energi yang rendah menjadi meteri berenergi tinggi melalui proses fisik, biologis, dan kimia atau kombinasi dengan teknolagi konversinya [3]

Dengan menjadi prodak yang lebih bemanfaat dan bernilai jual dengan menjadikan biobriket, yang bisa di produksi secara berkelanjutan dengan ketersediannya, merupakan sumber energi alternatif dari tanaman karet (havea brasiliensis), Dalam 1 (satu) hektar tanaman karet populasi sekitar 500 pohon produk utamanya berupa getah (lateks), umur lebih dari 30 tahun dapat 
menghasilkan lebih dari jumlah $150 \mathrm{~kg}$ biji total luas perkebuanan karet mencapai 3 juta hektar terluas didunia [4].

Dalam penelitian ini penggunaan perekat dapat pengikat partikel material bahan menjadi lebih baik dengan pemilihan perekat dari glyserin yang memiliki sifat fisik bertekstur kental bersifat higroskopis tidak beracun dan tidak berbahaya.

Glyserin merupakan hasil samping dari reaksi pembentukan biodesel sekitar $40 \%$ dari total proses pembuatan biodiesel dalam penggunaan sebagai bahan perekat merupakan salah satu dapat mengikat partikel karena memiliki sifat densitas $0,841 \mathrm{~g} / \mathrm{cm}^{3} 70$ ${ }^{\circ} \mathrm{C}$, viskositas $34 \mathrm{cP}$, fase cair $30^{\circ} \mathrm{C}, 1 \mathrm{~atm}$, titik beku $17,9{ }^{\circ} \mathrm{C}$, titik didih $290{ }^{\circ} \mathrm{C}$ dan nilai kalor $1353 \mathrm{kkal} / \mathrm{kg}$ banyak dilakukan penelitian.

Rasio glyserin dimanfaatkan sebagai bahan baku untuk energi alternatif dari limbah biodisel yang dicampur dengan biomassa adalah $30 \%$, menghasilkan peningkatan kepadatan pada pembuatan biobriket [5]. Sedangkan perekat glyserin mentah dengan kemurnian 84,5 \% dari limbah biodiesel dapat meningkatkan efisiensi termal pada proses pembakaran briket menghasilkan emisi rendah [6].

\section{METODE PENELITIAN}

Dalam penelitian ini dilakukan dengan menggunakan metode eksperimental, dengan pengamatan secara langsung mengetahui karakteristik pembakaran biobriket kulit dan cangkang karet, pada proses pembakaran berlangsung dengan merekam semua data visualisai pembakaran mengunakan kamera.

Dari pengujian karakteristik pembakaran akan diambil data meliputi kecepatan awal pembakaran, lamanya proses pembakaran, perubahan massa biobriket sampai menjadi abu, temperatur api pembakaran.
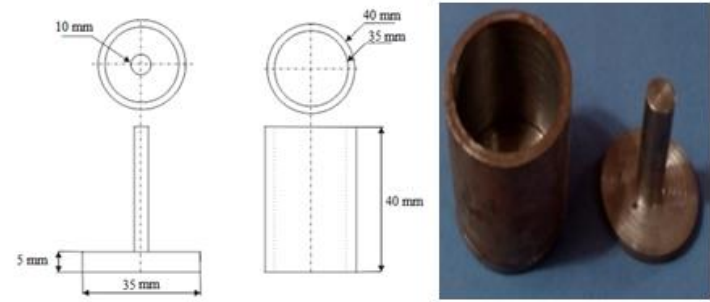

Gambar 1. Cetakan biobriket

Dalam penelitian ini biobriket dibuat dengan perbandingan campuran dari kulit dan cangkang karet yakni : $0 \%: 91 \% ; 45,5 \%$ : $45,5 \% ; 55 \%: 36 \% ; 64 \%: 27 \% ; 91 \%$ : 0 $\%$ dengan perekat $9 \%$ berbentuk silinder lingkaran yang diberikan tekanan sebesar 20 $\mathrm{kg} / \mathrm{cm}^{2}$. Cetakan biobriket dan variasi campuran biobriket dapat dilihat pada Gambar 1 dan 2.

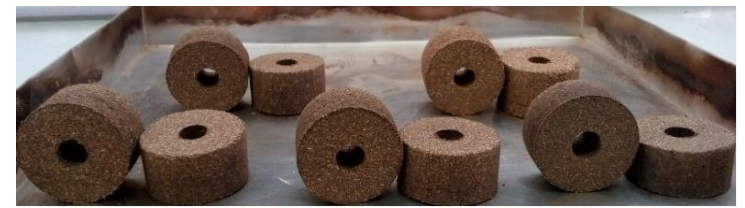

Gambar 2. Variasi campuran biobriket

Hasil penelitian akan mendapatkan sifat fisik biobriket yaitu kadar air (moisture), kadar abu (ash), zat - zat mudah menguap (volatile matter), karbon tetap (fixed carbon) dan nilai kalor (heating value). Dalam penelitianbeberapa parameter dijaga konstan seperti, tekanan pengepresan biobriket sebesar $20 \mathrm{~kg} / \mathrm{cm}^{2}$, waktu pengeringan biobriket selama 60 menit dengan teperatur $110^{\circ} \mathrm{C}$, temperatur heater listrik untuk pembakaran $\pm 600^{\circ} \mathrm{C}$, pengujian sifat fisik dengan standar uji SNI 13 - 1477 - 1994 dan jenis pembakaran yang digunakan adalah pembakaran difusi.

Dalam proses pembakaran biobriket mengunakan heater listrik dengan 450 watt, dengan temperatur herater mencapai $\pm 600^{\circ} \mathrm{C}$ yang berfungsi sebagai pemicu nyala api pada biobriket setelah terbakar semua bagian maka heater listrik dimatikan pengujian akan direkam menggunakan kamera untuk temperatur nyala api menggunakan alat data logger skema penelitian dapat dilihat pada Gambar 3.

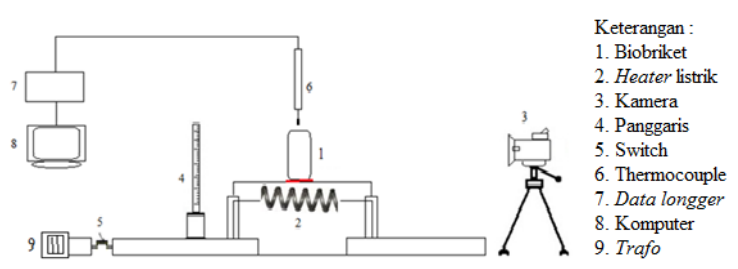

Gambar 3. Skema instalasi peralatan penelitian

\section{HASIL DAN PEMBAHASAN}

Dari data hasil pengujian tentang karakteristik pembakaran dan sifat - fisik biobriket kulit dan cangkang karet dengan perekat glyserin $9 \%$, miningkatkan kepadatan bahan baku pembuatan biobriket dengan 
melakukan pengeringan dengan temperatur $110{ }^{\circ} \mathrm{C}$ dapat menurunkan kadar air pada biobriket yang dihasilkan sehingga pada proses pembakaran akan mempercepat proses penguapan dan mempercepat penyalaan awal pembakaran. Untuk pembahasan tentang karakteristik pembakaran adalah sebagai berikut:

\section{Waktu penyalaan awal biobriket}

Pada proses pembakaran biobriket dari variasi campuran kulit dan cangkang karet tersebut tidak langsung terbakar memerlukan waktu untuk berubah fase daru pada menjadi gas, kemudian dari uap yang dihasilkan akan terbakar dan membetuk nyala api dapat dilihat pada Gambar 4 dibawah ini.

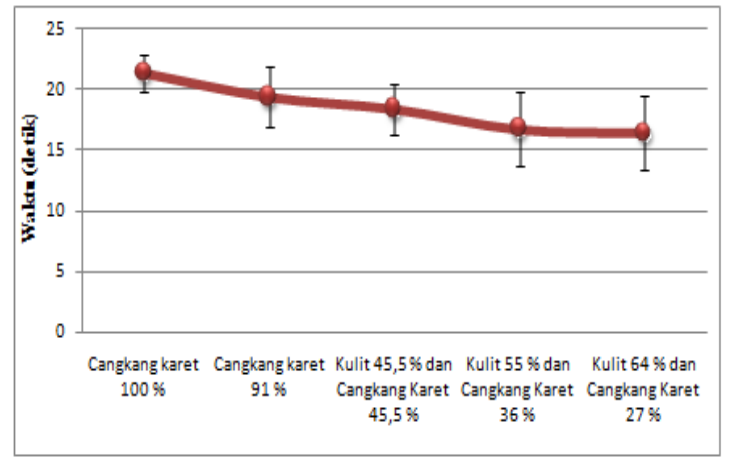

Gambar 4 Waktu penyalaan awal biobriket.

Proses pembakaran biobriket berlangsung waktu tercepat terjadinya nyala api pada penggunaan kulit karet $91 \%$ sebesar 16,4 detik, dibandingkan dengan penggunaan campuran cangkang karet $91 \%$ yang memerlukan waktu menyala 21,4 detik, maka untuk tercepat untuk penyalaan awal pada variasi campuran biobriket kulit $64 \%$ dan cangkang karet $27 \%$ dengan waktu 16,7 detik, karena dengan penambahan kulit karet yang berupa serat mempermudah penyalaan awal yang memerlukan waktu singkat dalam pengeringan sehingga mempercepat terjadinya api.

\section{Lama waktu proses pembakaran}

Pada proses pembakaran biobriket dari variasi campuran kulit dan cangkang karet berlangsung lama karena dipengaruhi oleh stuktur bahan yang memiliki kerapatan, keras, berat jenisnya lebih besar dan kandungan airnya masih cukup besar untuk berubah fase untuk terbakar kondisi demikian akan memperlambat penguapan yang tersimpan didalamnya. semakin besar perubahan massa berubah menjadi bara api mengakibatkan reaksi penguapan semakin cepat pada biobriket akan terjadi peningkatan laju pembakaran dan massannya semakin berkurang, dapat dilihat pada Gambar 5 dibawah ini.

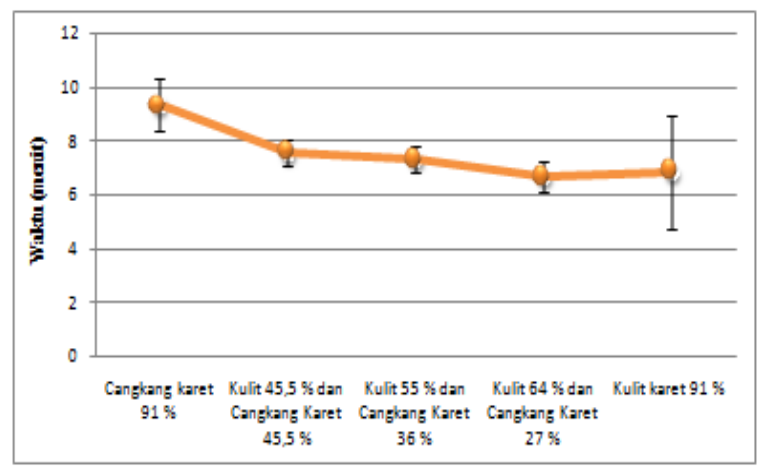

Gambar 5 Lama waktu proses pembakaran

Pada biobriket dengan penggunaan cangkang karet $91 \%$ memiliki waktu perubahan massa pembakaran yang lama sebesar 9,53 menit dibandingkan dengan penggunaan campuran kulit karet $91 \%$ yang memerukan waktu cepat untuk massa terbakar sebasar 6,87 menit. Maka dari grafik diatas terlihat pada variasi campuran biobriket waktu yang paling lama padam pada campuran biobriket kulit 45,5 $\%$ dan cangkang karet $45,5 \%$ sebesar 7,58 menit. diketahui bahwa lama pembakaran pada biobriket semakin cepat massa biobriket akan berkurang ketika seluruh permukaan mendekati bara api hal ini disebabkan seluruh bagian biobriket sudah menjadi bara api yang menyebabkan api pembakaran padam yang tersisa hanya bara api.

\section{Tinggi Api Pembakaran Pada Biobriket}

Pada proses pembakaran biobriket yang berlangsung pada setiap variasi campuran biobriket, yang mempengaruhi oleh kecepatan penguapan serta kecepatan bereaksi dengan udara sekitar, maka tinggi api pembakaran pada biobriket tertinggi pada kulit karet $91 \%$ sebesar 140,803 mm, Sehingga semakin besar campuran kulit karet pada setiap variasi 
biobriket akan terjadi peningkatan tinggi api dimana semakin besar gas yang terbentuk oleh penguapan maka energi nyala pada biobriket maka semakin tinggi.

Maka peningkatan tertinggi nyala api pada variasi biobriket campuran kulit $64 \%$ dan cangkang karet $27 \%$ sebesar $162,235 \mathrm{~mm}$. Hal ini menyebabkan dengan penggunaan kulit karet akan mempercepat rambatan api keseluruh bagian biobriket yang dapat dilihat dari kandungan pada kulit karet memiliki zat yang mudah menguap (volatille matter), dengan nilai $69,711 \%$ dibandingkan dengan cangkang karet sebesar $66,305 \%$, hal tersebut ditunjukkan pad Gambar 6.

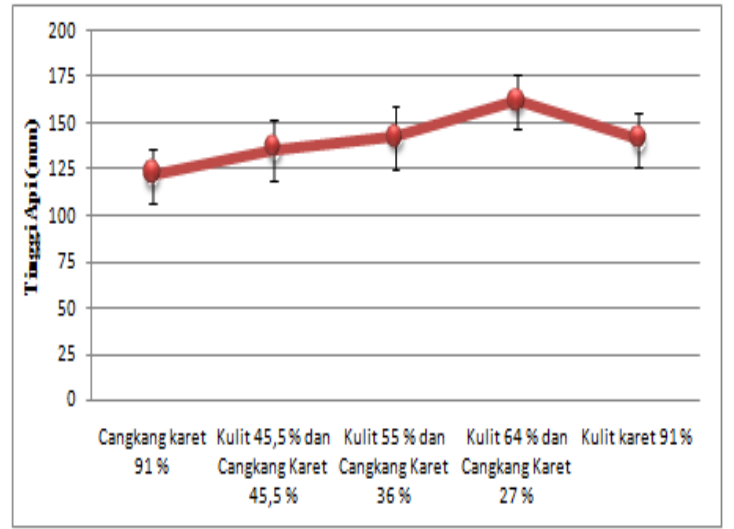

Gambar 6 Tinggi api maksimum proses pembakaran

\section{Temperatur pembakaran biobriket}

Dalam proses pembakaran biobriket energi panas digunakan untuk memutus ikatan bahan bakar biobriket yang mengakibatkan energi radikal bebas saling bertubrukan sehingga terjadinya perubahan fase bahan bakar dari padat ke gas bereaksi dan berlangsung terus menerus sehingga menghasilkan peningkatan temperatur tinggi pada pembakaran.

Pada proses pembakaran biobriket berlangsung untuk setiap variasi campuran biobriket temperatur tertinggi pada cangkang karet $91 \%$ dengan temperatur $959,240{ }^{\circ} \mathrm{C}$, maka untuk setiap variasi campuran akan meningkat dengan penggunaan campuran pada cangkang karet di bandingkan dengan penggunaan campuran pada kulit karet $91 \%$ yang memilik temperatur $918,562{ }^{\circ} \mathrm{C}$. Sehingga pada setiap variasi campuran biobriket dengan temperatur pembakaran akan menurun dengan peningkatan penggunaan campuran pada kulit karet seperti pada Gambar 7.

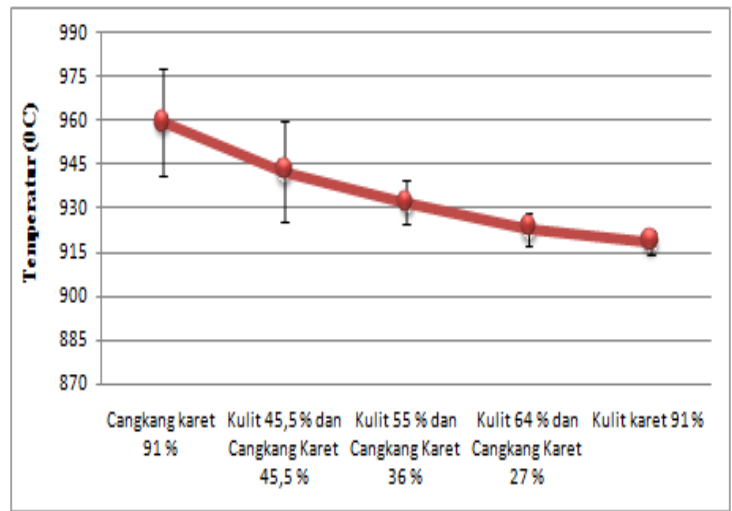

Gambar 7. Temperatur pembakaran biobriket.

\section{Perubahan massa biobriket sampai menjadi} abu

Perubahan massa pada setiap variasi campuran biobriket pada proses pembakaran hingga menjadi abu, dengan melihat perubahan massa selama proses pembakaran terhadap waktu dimana untuk semua variasi campuran biobriket yang terendah dengan penggunaan kulit karet $91 \%$ sebesar 2.15 gram.

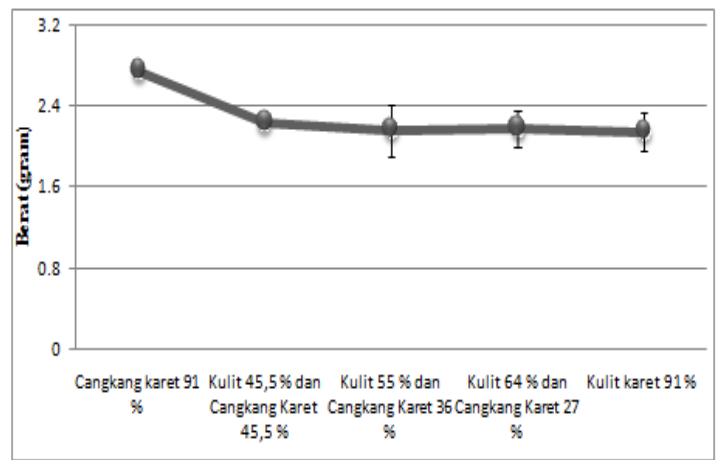

Gambar 7. Perubahan massa biobriket sampai menjadi abu

Sedangkan untuk variasi campuran biobriket pada kulit $64 \%$ dan cangkang karet $27 \%$ sebesaar 2.16 gram dengan penambahan cangkang karet pada setiap variasi biobriket maka perubahan massa setiap biobriket akan meningkat $2.10 \%$

\section{Kandungan biobriket}

Dari data hasil pengujian nilai kandungan setiap variasi biobriket dari kulit dan cangkang 
karet dengan perekat glyserin seperti pada Gambar 8 yang berhubungan dengan bahan bakar alternatif mengetahui senyawa kandungan dalam biobriket yang dihasilkan maka dapat diketahui seberapa besar potensinya sebagai bahan bakar alternatif yang dapat mengetahui karakteristik pembakaran dengan mengamati proses pembakaran serta sifat nyala yang diamati waktu penyalaan untuk menguatkan hasil pengujian yang dilakukan jenis pembakaran difusi dengan model biobriket.

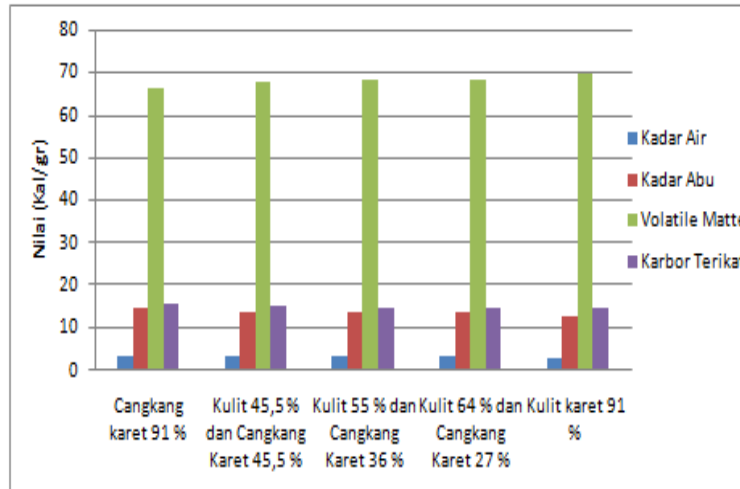

Gambar 8. Nilai kadar air, kadar abu, volatile matter.

Dari hasil pengujian bahwa nilai kalor tanpa penggunaan glyserin pada Sehingga pada campuran cangkang karet yang memiliki nilai kalor sebesar 4572,3456 Kcal/gram. Maka seiring dengan banyaknya penambahan kulit karet yang memiliki nilai kalor 5503,9838 $\mathrm{Kcal} / \mathrm{gram}$ akan meningkatkan nilai kalor pada biobriket seperti pada Gambar 9 .

Maka untuk nilai kalor tertinggi pada variasi campuran biobriket pada kulit $64 \%$ dan cangkang karet $27 \%$ sebesar 5313,9230 $\mathrm{Kal} / \mathrm{gr}$, karena memiliki pencampuran yang baik dari pengujian semakin tinggi nilai kalor yang dipengaruhi oleh struktur bahan, kadar air, abu sehingga energi panas yang dihasilkan akan mempercepat menguapkan kandar air yang dapat meningkatkan nilai kalor sedangkan pada kadar abu tinggi dapat menurunkan nilai kalor yang disebabkan oleh kotoran abu yang berupa sulika pada abu yang tidak bisa terbakar yang menyebabkan penggumpalan dan penyubatan.

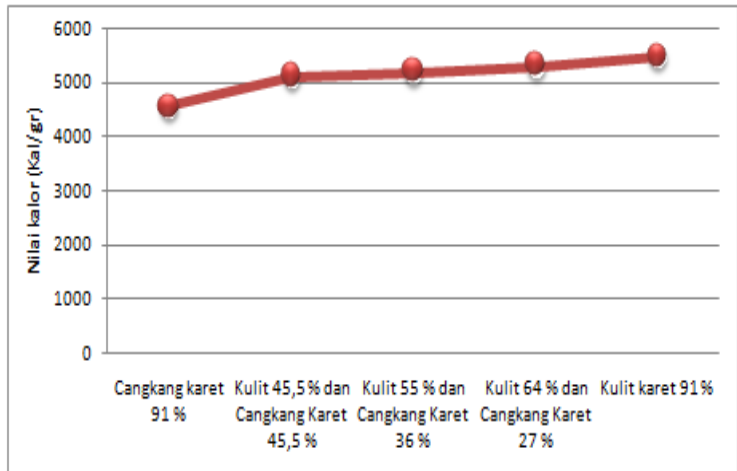

Gambar 9. Nilai kalor biobriket.

\section{Urutan proses pembakaran}

Pada proses pembakaran biobriket dari variasi campuran kulit dan cangkang karet karet melalui tahapan sangat panjang pada saat diberikan energi aktivasi dari heater listrik menghasilkan panas yang ditransfer secara konduksi maka ada perubahan fase biobriket dari padat menjadi asap kemudian menjadi gas hingga terbentuk nyala api serta terjadi perubahan massa biobriket menjadi abu, terlihat jelas pada saat proses pembakaran berlangsung setiap variasi campuran biobriket dengan tahapan penguapan pada saat dipanaskan memerlukan waktu berubah fase menjadi gas sebelum terbakar, gas yang terbentuk bergerak ke atas karena memiliki berat jenis yang ringan dari pada udara sekitar, sehingga semakin banyak massa biobriket yang menguap menjadi gas maka nyala api yang dihasilkan lebih besar, untuk panjangnya api yang disebabkan antara gas reaktan jauh lebih cepat dari kecepatan pembakaran sehingga tinggi api ditentukan oleh perilaku aliran, gerakan api, dan kesetabilan nyala.

\section{Proses pembakaran pada biobriket murni Cangkang Karet $91 \%$}

Dalam proses pembakaran memerlukan waktu penyalaan awal 23 detik hanya membakar bagian permukaan biobriket. pada waktu 6,09 menit terlihat penguapan bahan biobriket yang menyebabkan api semakin tinggi yang bewarna merah merupakan kaya akan bahan bakar, memiliki waktu paling lama selama proses pembakaran karena memiliki sifat bahan keras serta memliki kepadatan yang tinggi, untuk apinya mulai padam pada waktu 6,71 minit terjadi perubahan betuk api yang semakin mengkerucut dan mengecil massa 
biobriket sudah terbakar sehingga api padam pada waktu 8,48 menit, hal ini ditunjukkan pada Gambar 10.

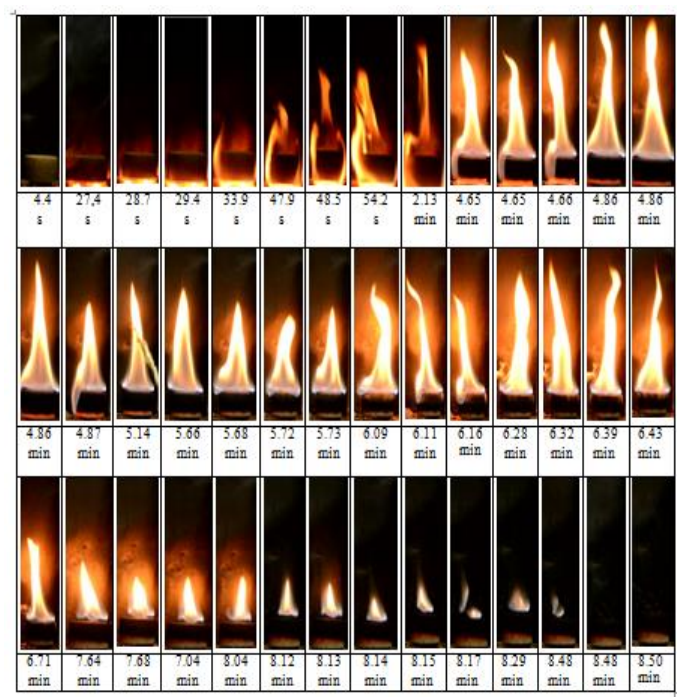

Gambar 10 Proses pembakaran biobriket cangkang karet $91 \%$.

\section{Proses pembakaran pada biobriket variasi campuran kulit $45,5 \%$ dan cangkang karet $45,5 \%$}

Dalam proses pembakaran memerlukan waktu penyalaan awal 22 detik, terlebih dahulu terjadi penguapan biobriket dengan terbetuk asap pada menit 45,1 detik kemudian terjadi peningkatan nyala api. Terjadinya peningkatan luasan bara api yang terbentuk maka kecepatan reaksi penguapan pembakaran semakin cepat sehingga api hasil pembakaran api cenderung tidak stabil dikarenakan kecepatan gas reaktan lebih cepat terlihat pada waktu 4,70 menit, sehingga menyebabkan temperatur awal proses pembakaran menurun sehingga api mulai mengerucut pada waktu 6.59 menit luasan bara api terbetuk meningkat dan bahan bakar semakin berkurang menyebabkan proses padamnya api pembakaran yang di ikuti dengan asap pada waktu 7,33 menit menit seperti pada Gambar 11.

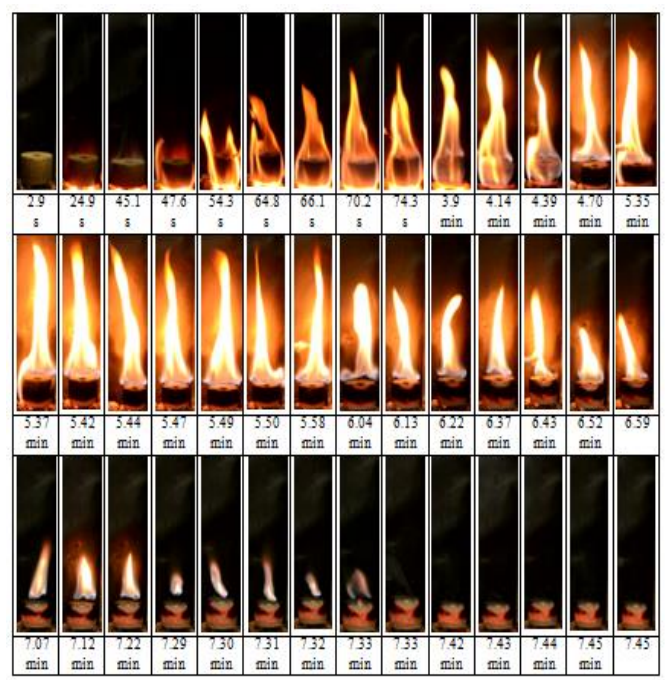

Gambar 11 Proses pembakaran biobriket campuran kulit 45,5\% dan cangkang karet $45,5 \%$

\section{Proses pembakaran pada biobriket variasi campuran kulit $55 \%$ dan cangkang karet $36 \%$ \\ Untuk proses pembakaran memerlukan} waktu penyalaan awal 20 detik, dengan keluarnya asap semakin sedikit jumlah asap dalam api pembakaran warna api akan berubah dari merah ke kuningan dan kemudian warna biru warna api menunjukan perbedaan radiasi api pembakaran serta kecepatan reaksi yang terjadi dalam api maka akan semakin tipis terbentuknya api pada waktu 5.85 menit.

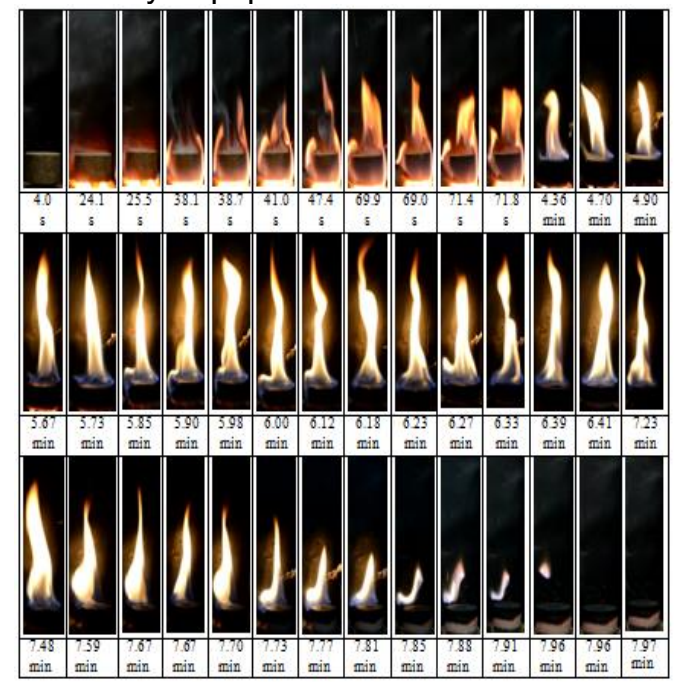

Gambar 12 Proses pembakaran biobriket campuran kulit $55 \%$ dan cangkang karet 36 $\%$ 
Tebentuknya bara api pada proses pembakaran dapat membantu kecepatannn reaksi bahan bakar dan meningkatkan tinggi api menyebabkan massa biobriket berkurang yang pada waktu 6,48 menit nyala api semakin mengecil dan mengerucut sehingga pada proses pembakaran akan mulai padam $n$ pada waktu 7,01 menit, hasil ini ditunjukkan pada Gambar 12.

\section{Proses pembakaran pada biobriket variasi campuran kulit $64 \%$ dan cangkang $27 \%$}

Untuk proses pembakaran memerlukan waktu penyalaan awal 20 detik, nyala api sesuai dengan bentuknya proses pembakaran hanya membakar bagian permukaan biobriket pada waktu 53,6 detik, terjadi penguapan bahan bakar dengan membetuk asap pada saat api mulai membesar asap semakin berkurang hingga mengkerucut pada waktu 3,44 menit, meningkatkan pembentukan bara api menyebabkan massa biobriket berkurang yang menyebabkan pada waktu 6,48 menit nyala api semakin mengecil dan mengerucut sehingga pada proses pembakaran akan mulai padam pada waktu 7,01 menit, ditampilkan oleh Gambar 13.

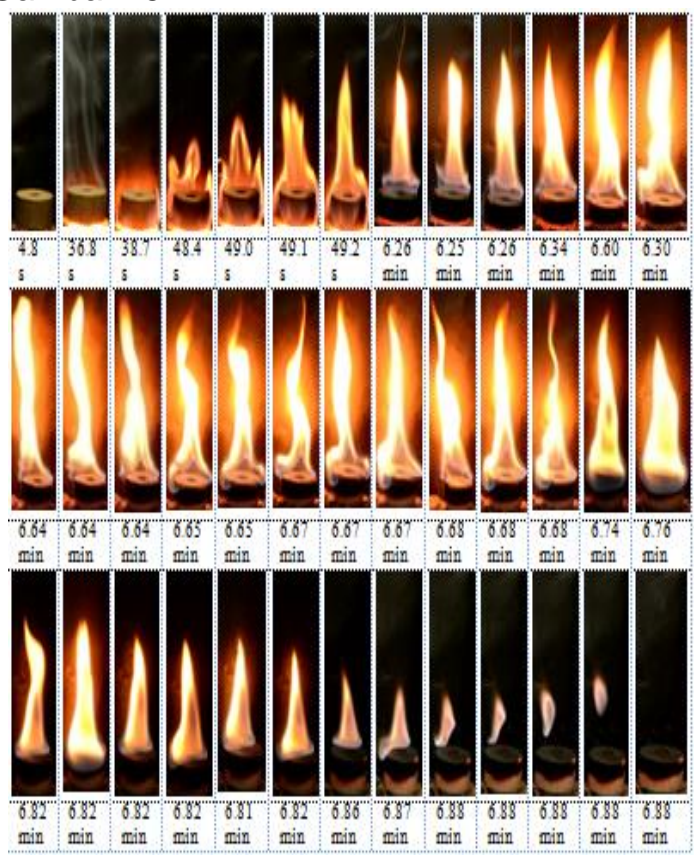

Gambar 13 Proses pembakaran biobriket campuran kulit $64 \%$ dan cangkang karet 27 $\%$

\section{Proses pembakaran pada biobriket murni cangkang karet $91 \%$}

Pada proses pembakaran memerlukan waktu penyalaan awal 19 detik yang terjadi pada bagian bawah yang dekat dengan sumber energi panas sehingga permukaan bagian bawah akan sebagian terbetuk bara api yang lebih cepat untuk penguapan biobriket maka laju reaksi pembakaran sangat cepat yang disertai dengan tinggi api pada pembakaran pada waktu 6,93 menit nyala api tidak stabil karena kecepatan reakatan lebih cepat dari kecepatan pembakaran pada massa biobriket sudah terbentuk bara api sehingga nyala api mulai mengecil waktu 8,04 menit menyebabkan nyala api mulai padam yang di ikuti dengan asap pembakaran pada waktu 9,25 menit, hal ini ditunjukkan pada Gambar 14.
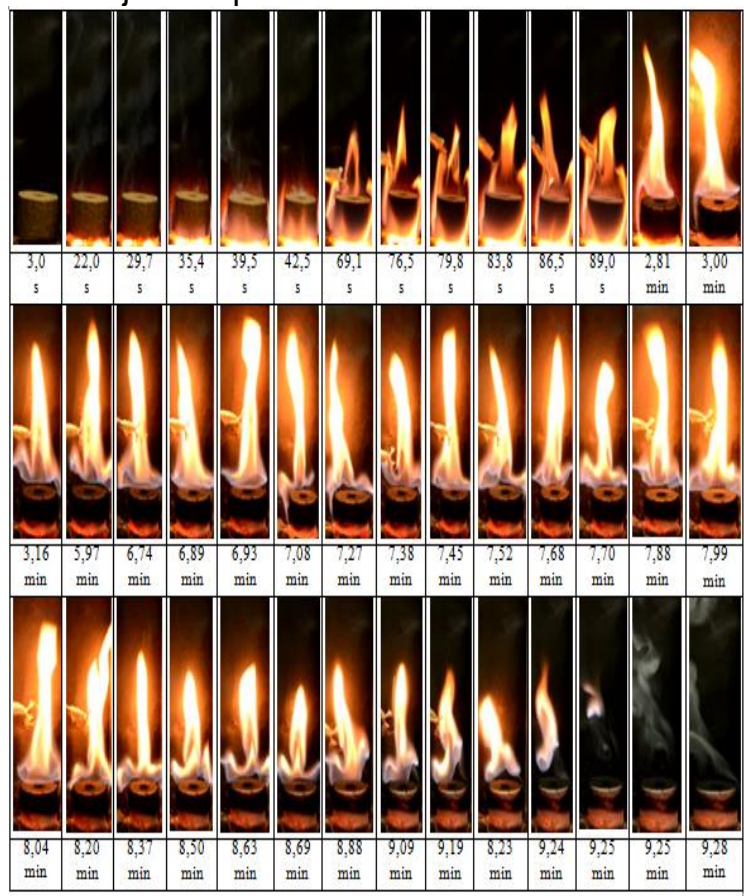

Gambar 14 Proses pembakaran biobriket kulit $91 \%$

\section{KESIMPULAN}

Berdasarkan data hasil penelitan yang telah dilakukan, dapat disimpulkan beberapa hal sebagai berikut:

1. Pada karakteristik pembakaan pada biobriket kulit dan cangkang karet, dengan penggunaan campuran pada cangkang karet api cenderung stabil, karena memiliki kadar volatile matter redah sebesar 
$66,3058 \%$ dibandingkan dengan kulit yang lebih tinggi sebesar 69,7111\%.

2. Penambahan campuran perekat glyserin 9 $\%$ pada biobriket kulit dan cangkang karet tidak mudah rapuh dengan penggunaan perekat meningkatkan kadar abu pada biobriket kulit dan cangkang karet.

3. Laju pembakaran setiap variasi biobriket kulit dan cangkang karet dengan penyalaan awal yang lebih cepat terjadinya api pada variasi campuran kulit $64 \%$ dan cangkang $27 \%$ dengan waktu rata- rata 16,7 detik.

4. Perubahan massa biobriket paling cepat dengan waktu rata - rata 6,71 menit pada variasi campuran biobriket yang memiliki massa terendah pada campuran kulit $55 \%$ dan cangkang karet $36 \%$ sebesaar 2,16 gram.

5. Pada proses pembakaran biobriket dengan penambahan pada cangkang karet dapat meningkatkan temperatur pembakaran maka setiap variasi biobriket temperatur yang tertingi pada variasi biobriket kulit dan cangkang karet 45,5: 45,5 rata - rata sebesar $959,624^{\circ} \mathrm{C}$.

\section{DAFTAR PUSTAKA}

[1]. Sugiyono, Agus., Anindhita, Boedoyo, M. Sidik, Adiarso. 2015. Pengembangan Energi untuk Mendukung Pembangunan Berkelanjutan. Outlook Energi Indonesia. Jakarta : Pusat Teknologi Pengembangan Sumberdaya Energi BPPT. ISBN : 978602-1328-04-0

[2]. Sugiyono, Agus., Anindhita, Boedoyo, M. Sidik, Adiarso. 2015. Pengembangan Energi untuk Mendukung Program Subsitusi BBM. Outlook Energi Indonesia. Jakarta : Pusat Teknologi Pengembangan Sumberdaya Energi BPPT. ISBN : 978602-1328-02-6

[3]. Carlos, Romel M., Do Ba Khang. 2008. Characterization of biomass energy projects in Southeast Asia. Biomass and Bioenergy Jounals. Elsevier. Vol. 32. Issue. 6. pp. 525-532.

[4]. Nazaruddin. 1992. Budidaya dan Pengolahan Strategi Pemasaran. Jakarta : PT Penebar Swadaya.

[5]. Sakkampang, Chatcharin., Wongwuttanasatian, Tanakorn. 2014. Study of Ratio of Energy Consumption and Gained Energy During Briquetting Process for Glycerin-Biomass Briquette Fuel. Fuel Journals. Elsevier. Vol. 115. pp. 186-189

[6]. Chaiyaomporn, K., Chavalparit, Orathai .2010. Fuel Pellets Production from Biodiesel Waste. Environ Asia.Vol. 3 No. 1. pp. 103-110. DOI 10.14456/EA.2010.14 